\title{
Distinct taxonomic position of the Madagascar stonechat (Saxicola torquatus sibilla) revealed by nucleotide sequences of mitochondrial DNA
}

\author{
Friederike Woog • Michael Wink · \\ Eskandar Rastegar-Pouyani . \\ Javier Gonzalez $\cdot$ Barbara Helm
}

Received: 1 March 2007 /Revised: 30 January 2008 / Accepted: 4 February 2008/Published online: 29 February 2008

(c) Dt. Ornithologen-Gesellschaft e.V. 2008

\begin{abstract}
Stonechats (genus Saxicola) are passerine birds with an extraordinarily large breeding distribution. Recent studies provide strong evidence that the taxon shows far greater geographic differentiation than originally suspected, with African, Siberian and European stonechats forming distinct, monophyletic groups that have been suggested to be species in their own right. Here, we present additional data on the geographic differentiation among African stonechats, Saxicola torquatus. Nucleotide sequences of the mitochondrial $\mathrm{NADH}$ dehydrogenase subunit 2 and cytochrome $b$ genes indicate that the stonechats from Eastern Madagascar (Saxicola t. sibilla) form a distinct clade and that they constitute a monophyletic group with stonechats from mainland eastern Africa (Saxicola t. axillaris) and La Réunion (Saxicola tectes). The genetic and morphological data suggest that the Madagascar stonechat is very likely to be a distinct species, Saxicola
\end{abstract}

Communicated by T. Friedl.

\section{F. Woog $(\bowtie)$}

Staatliches Museum für Naturkunde Stuttgart,

Rosenstein 1, 70191 Stuttgart, Germany

e-mail: woog.smns@naturkundemuseum-bw.de

M. Wink · E. Rastegar-Pouyani · J. Gonzalez Institut für Pharmazie und Molekulare Biotechnologie, Ruprecht-Karls-Universität Heidelberg, Im Neuenheimer Feld 364, 69120 Heidelberg, Germany e-mail: wink@uni-hd.de

E. Rastegar-Pouyani

e-mail:

B. Helm

Max Planck Institute for Ornithology,

Von-der-Tann-Str. 7, 82346 Andechs, Germany

e-mail: helm@orn.mpg.de sibilla (Linnaeus 1766). However, further studies are needed to verify this. A detailed description of the plumage and various external body measurements is given.

Keywords Mitochondrial DNA - Morphometrics · Phylogeny $\cdot$ Saxicola $\cdot$ Taxonomy

\section{Introduction}

According to recent genetic analyses, several of the stonechats belonging to the palaeotropic species complex "Saxicola torquatus" form species in their own right. The two allospecies $S$. rubicola and S. maurus, for example, can be clearly differentiated based on nucleotide sequences of mitochondrial (mt)DNA (Wittmann et al. 1995; Wink et al. 2002a, b; Urquhart 2002), and these two taxa are in turn distinct from the African stonechat $S$. torquatus. African stonechat groups belonging to the species complex of $S$. torquatus should probably be considered sister taxa of the European stonechat groups S. rubicola, S. maurus and S. dacotiae (the latter is found on Fuerteventura in the Canary Islands and lacks a black throat). For the at least 12 African subspecies, species status is still being discussed and subject to debate, paralleling the situation within the European and Asian Stonechat groups. However, data are still scarce.

On Madagascar, only one subspecies, Saxicola torquatus sibilla (L.) 1766, is currently recognised by most researchers, although two other forms have been described: Saxicola torquatus ankaratrae (Salomonsen 1934) and S. torquatus tsaratananae (Milon 1950).

To investigate the systematic position of $S$. $t$. sibilla from Madagascar, we used $S$. torquatus axillaris (Shelley $1885)$ as representative of mainland Africa and S. tectes (Gmelin, 1789) from the island of La Réunion (Fig. 1). 
Saxicola tectes is largely accepted as a separate species. Similar to $S$. dacotiae, it lacks a black throat and its plumage is quite distinct.

Here, we present new results pertaining to the systematic position and status of $S$. $t$. sibilla based on nucleotide sequences of mitochondrial cytochrome $b(c y t b)$ and NADH dehydrogenase subunit $2(n d 2)$ genes and give a detailed description of the plumage and the external morphology of the taxon.

Distribution, habitat and breeding season of stonechats studied

Stonechats (S. $t$. sibilla) are widespread on Madagascar. They are found in a variety of habitats, including montane heathland and scrub, the open areas nearby, forest clearings and also in secondary growth, at elevations from sea level to $2500 \mathrm{~m}$ a.s.l. (Morris and Hawkins 1998, own observations). Nesting has been observed between July and January, peaking in October (Langrand 1990, own observations).

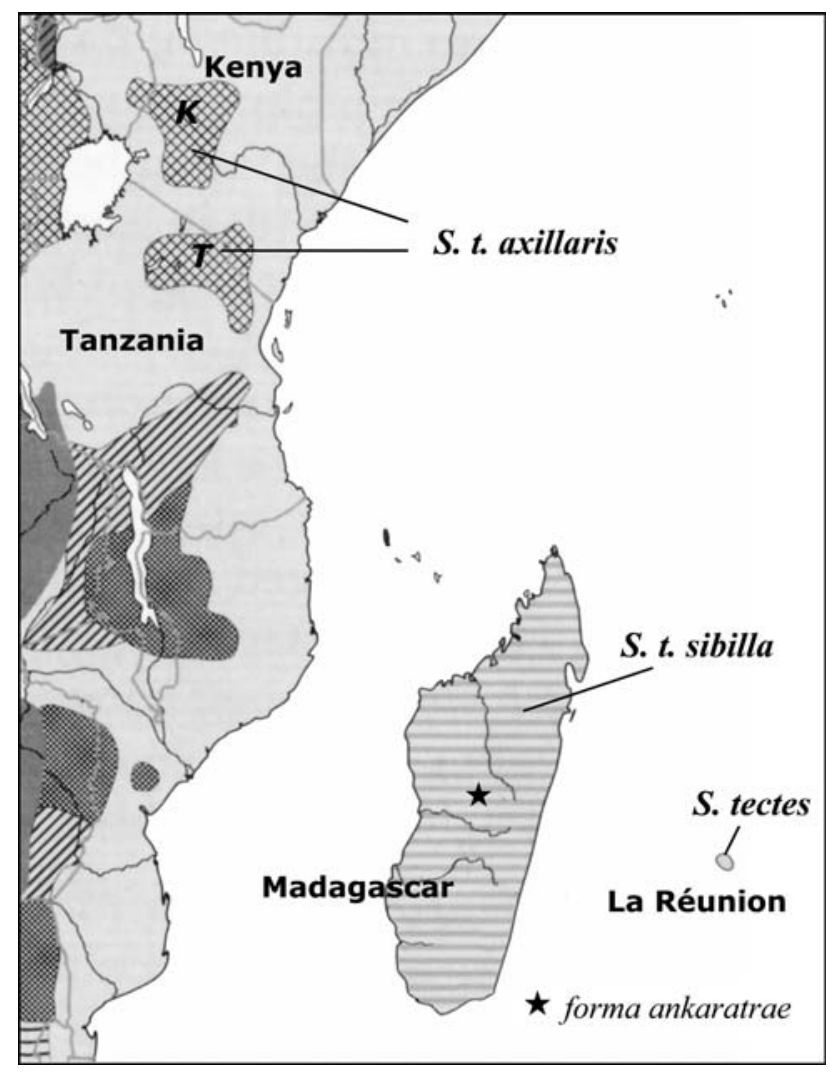

Fig. 1 Distribution map for Saxicola torquatus sibilla, S. tectes and S. t. axillaris, modified from Urquhart (2002). Samples from the other taxa indicated by shading were not available
Saxicola tectes is endemic to the island of La Réunion (elevation 800 to over $3000 \mathrm{~m}$ a.s.l.), thrives in a variety of habitats, including tree heather, and breeds between midOctober to the end of January (Urquhart 2002). It is not known to migrate large distances.

Saxicola t. axillaris ranges throughout the highlands of Kenya, northern and western Tanzania, including the Lake Victoria basin, western and southern Uganda, Rwanda, Burundi and eastern Zaire (Keith et al. 1992, Urquhart 2002). It occurs in alpine heathlands, moorlands, grassy hillsides but also in bush and forest habitats at elevations ranging from 1200 to $3200 \mathrm{~m}$ a.s.l. (Britton 1980). These stonechats are paired year round, defend all-purpose territories (Keith et al. 1992), are seasonal breeders and do not exhibit migratory behaviour.

\section{Methods}

Samples

The origins of the samples examined are listed in Table 1. The origins of Eurasian stonechats are described in Wink et al. (2002a, b). The Malagasy samples were taken at Maromizaha (Andasibe, eastern Madagascar), located approximately $150 \mathrm{~km}$ east of the capital Antananarivo (elevation approximately $1200 \mathrm{~m}$ a.s.l.). Blood samples of stonechats from mainland Africa (S. t. axillaris) originated from the Lake Nakuru region, Kenya $\left(0^{\circ} 14^{\prime} \mathrm{S}, 36^{\circ} 0^{\prime} \mathrm{E}\right.$; Fig. 1, region $\mathrm{K}$ ) and from the Arusha region near Mount Meru, Tanzania $\left(3^{\circ} 10^{\prime} \mathrm{S}, 36^{\circ} 40^{\prime} \mathrm{E}\right.$; Fig. 1 , region T) from birds caught in the wild at approximately $2000 \mathrm{~m}$ a.s.l. (Scheuerlein and Gwinner 2006). Samples of other stonechat taxa from mainland Africa were not available.

On La Réunion, blood samples were taken from nestlings (Wink et al. 2002b).

The blood samples $(200-300 \mu \mathrm{l})$ were obtained from the brachial vein and preserved in storage buffer containing $10 \%$ EDTA, $1 \%$ sodium dodecyl sulphate, $0.5 \%$ $\mathrm{NaF}, 0.5 \%$ thymol and $100 \mathrm{~m} M$ Tris, pH 7.4 (Wink 2006). For some taxa, tissue was used as outlined in Wink et al. (2002a, b).

DNA extraction, PCR amplification and sequencing

DNA was extracted from blood/tissue samples using the proteinase $\mathrm{K}$ protocol (Wink 2000). The mitochondrial $c y t b$ gene was amplified by PCR and sequenced directly according to Wink et al. (2002a, b). The mitochondrial $n d 2$ gene was amplified by PCR using the primers metl and asn (Zink et al. 2006). The PCR amplifications were performed in $50-\mu \mathrm{l}$ reaction volumes containing $2.5 \mathrm{mM} \mathrm{MgCl}_{2}$, $10 \mathrm{mM}$ Tris (pH 8.5), $50 \mathrm{mM} \mathrm{KCl}, 100 \mu \mathrm{M}$ dNTPs, $0.8 \mathrm{U}$ 
Table 1 Origin, collection codes and accession numbers of taxa sequenced in this study

\begin{tabular}{|c|c|c|c|c|}
\hline \multirow[t]{2}{*}{$\overline{\text { Species }}$} & \multirow[t]{2}{*}{ IPMB $\operatorname{code}^{\mathrm{a}}$} & \multicolumn{3}{|c|}{ GenBank accession numbers } \\
\hline & & $c y t b$ & $n d 2$ & Origin \\
\hline Luscinia luscinia & 4385 & EU190893 & EU190929 & Biebrza, Poland \\
\hline Luscinia luscinia & 4386 & EU190894 & EU190930 & Biebrza, Poland \\
\hline Saxicola rubetra & 4384 & EU190895 & EU190931 & Biebrza, Poland \\
\hline Saxicola rubetra & 4383 & EU190896 & EU190932 & Biebrza, Poland \\
\hline Saxicola $r$. hibernans & 10475 & EU190897 & EU190933 & Waterford, Ireland \\
\hline Saxicola rubicola & 4412 & EU190898 & EU190934 & Évora, Portugal \\
\hline Saxicola rubicola & 4387 & EU190899 & EU190935 & Scotland \\
\hline Saxicola rubicola & 4418 & EU190900 & EU190936 & Turkey, Ulu Dag \\
\hline Saxicola rubicola & 4419 & EU190901 & EU190937 & Turkey, Ulu Dag \\
\hline Saxicola rubicola & 4420 & EU190902 & EU190938 & Turkey, Ulu Dag \\
\hline Saxicola rubicola & 4421 & EU190903 & EU190939 & Turkey, Ulu Dag \\
\hline Saxicola rubicola & 10467 & EU190904 & EU190940 & Lake Neusiedl, Austria \\
\hline Saxicola dacotiae & 15403 & EU190905 & EU190941 & Fuerteventura, Canary Islands \\
\hline Saxicola dacotiae & 15402 & EU190906 & EU190942 & Fuerteventura, Canary Islands \\
\hline Saxicola caprata & 10462 & EU190907 & EU190943 & Southeast Asia (commercially obtained) \\
\hline Saxicola caprata & 10463 & EU190908 & EU190944 & Southeast Asia (commercially obtained) \\
\hline Saxicola tectes & 10502 & EU190909 & EU190945 & Takamaka, La Réunion \\
\hline Saxicola tectes & 10503 & EU190910 & EU190946 & Takamaka, La Réunion \\
\hline Saxicola tectes & 10504 & EU190911 & EU190947 & Takamaka, La Réunion \\
\hline Saxicola tectes & 10505 & EU190912 & EU190948 & Takamaka, La Réunion \\
\hline Saxicola torquatus sibilla & 32114 & EU190913 & EU190949 & Eastern Madagascar, Maromizaha \\
\hline Saxicola t. sibilla & 32115 & EU190914 & EU190950 & Eastern Madagascar, Maromizaha \\
\hline Saxicola $t$. sibilla & 32116 & EU190915 & EU190951 & Eastern Madagascar, Maromizaha \\
\hline Saxicola $t$. sibilla & 32117 & EU190916 & EU190952 & Eastern Madagascar, Maromizaha \\
\hline Saxicola maurus & 4413 & EU190917 & EU190953 & Near Dokutschaewka, Kazakhstan \\
\hline Saxicola maurus & 4414 & EU190918 & EU190954 & Near Dokutschaewka, Kazakhstan \\
\hline Saxicola maurus & 4415 & EU190919 & EU190955 & Near Dokutschaewka, Kazakhstan \\
\hline Saxicola maurus & 4417 & EU190920 & EU190956 & Near Dokutschaewka, Kazakhstan \\
\hline Saxicola torquatus axillaris & 10461 & EU190921 & EU190957 & Tanzania, Arusha region near Mt Meru \\
\hline Saxicola t. axillaris & 11696 & EU190922 & EU190958 & Tanzania, Arusha region near Mt Meru \\
\hline Saxicola t. axillaris & 11697 & EU190923 & EU190959 & Tanzania, Arusha region near Mt Meru \\
\hline Saxicola t. axillaris & 11699 & EU190924 & EU190960 & Tanzania, Arusha region near Mt Meru \\
\hline Saxicola $t$. axillaris & 11605 & EU190925 & EU190961 & Kenya, Lake Nakuru/Naivasha Region \\
\hline Saxicola t. axillaris & 11606 & EU190926 & EU190962 & Kenya, Lake Nakuru/Naivasha Region \\
\hline Saxicola t. axillaris & 11607 & EU190927 & EU190963 & Kenya, Lake Nakuru/Naivasha Region \\
\hline Saxicola $t$. axillaris & 11608 & EU190928 & EU190964 & Kenya, Lake Nakuru/Naivasha Region \\
\hline
\end{tabular}

${ }^{a}$ IPMB, Institut für Pharmazie und Molekulare Biotechnologie, Heidelberg University; nd2, NADH dehydrogenase subunit 2 gene; cytb, mitochondrial cytochrome $b$ gene

DFS Taq DNA polymerase (Bioron, Ludwigshafen, Germany), 300 ng DNA and 5 pmol of primers.

The cycling protocol consisted of an initial denaturation at $95^{\circ} \mathrm{C}$ for $5 \mathrm{~min}$, followed by 35 cycles of $95^{\circ} \mathrm{C}$ for $45 \mathrm{~s}$ (denaturation), $49^{\circ} \mathrm{C}$ for $50 \mathrm{~s}$ (annealing) and $72^{\circ} \mathrm{C}$ for 2 min (extension) and terminated with a final extension at $72^{\circ} \mathrm{C}$ for $10 \mathrm{~min}$. Before sequencing, PCR products were precipitated in $4 M \mathrm{NH}_{4} \mathrm{Ac}$ and ethanol (1:1:6), then centrifuged for $25 \mathrm{~min}$ at 13,000 rpm, washed in $70 \%$ ethanol and resolved in $20 \mu \mathrm{l}$ of distilled water.

A cycling sequencing reaction (total volume $5 \mu \mathrm{l}$ ) contained $1 \mu \mathrm{l}$ of reaction mix (according to the premix terminator protocol; Amersham Biosciences, Piscataway, $\mathrm{NJ}$ ), 5 pmol of one of the forward primers (metl or L347; 
Zink et al. 2006) and 1-2 $\mu$ l of the template. The cycling sequencing protocol consisted of 28 cycles of $20 \mathrm{~s}$ at $96^{\circ} \mathrm{C}$, $15 \mathrm{~s}$ at $49^{\circ} \mathrm{C}$ and $2.5 \mathrm{~min}$ at $60^{\circ} \mathrm{C}$. The sequencing products were diluted in $15 \mu \mathrm{l}$ distilled water and purified by Sephadex G-50 columns (Amersham Biosciences) and MultiScreen filter plates (Millipore Corp, Bedford, MA) following the manufacturer's instructions. The sequences were analysed by capillary electrophoresis using an automated sequencer MegaBACE 1000 (Molecular Dynamics, Amersham Pharmacia) and deposited at GenBank under the accession numbers listed in Table 1.

Sequence analysis and phylogenetic reconstruction

The sequences were aligned by BIoEDIT ver. 7.0.5 (Hall 1999). Basic statistics and $P$-distances were calculated with MEGA ver. 4.0 (Tamura et al. 2007). Phylogenetic trees were reconstructed using maximum likelihood (ML), maximum parsimony (MP) and neighbour-joining [NJ, using the Kimura-2-parameter model (Kimura 1980)] in PAUP* ver. 4.0b10a (Swofford 2001). The phylogenetic analyses were performed for both genes separately and concatenated. The MP and ML heuristic searches were performed with ten random stepwise additions, treebisection-reconnection branch-swapping and "multrees" option. We explored the model of sequence evolution that fits the data best using Modeltest ver. 3.7 (Posada and Crandall 1998). The best model was then used with the ML analyses. The robustness of the nodes was assessed by 1000 bootstrap replicates. Finally, the Thrush Nightingale Luscinia luscinia was used as an outgroup.

Morphometrics and plumage

We examined and measured 66 individuals of $S$. $t$. sibilla from the following museums: Muséum d'Histoire Naturelle Paris (MHNH, $n=43$ ), Naturkundemuseum Berlin (ZMB, $n=11$ ), Museum Alexander Koenig, Bonn (ZFMK, $n=6$ ), Staatliches Museum für Naturkunde Stuttgart (SMNS, $n=6$ ). We also examined wild samples $(n=24)$. The following measurements were taken (for methods, see Redfern and Clark 2001): wing length (maximum chord), tarsus length (minimum), bill width, bill depth, bill length (from the tip of the bill to the distal end of the nostril), bill length from bill tip to skull, distance of tip of outermost secondary to wing tip (Kipp), tail and weight (only for wild birds). The Kipp index was calculated as Kipp $\times 100 /$ wing-length (Kipp 1959). A high Kipp value indicates a more pointed wing, a low value a more rounded wing.

Measurements taken from study skins were not pooled with those of living birds because some measurements change when the skins dry. All measurements were exact to
$0.5 \mathrm{~mm}$. All measurements (wing, tail, tarsus, skull, beak measurements and Kipp index of males and females from Madagascar) were analysed using $t$ tests in MiNITAB (Minitab 2005). Significance levels were set at $P<0.05$. The plumage of all taxa studied has been described by Urquhart (2002) in much detail. Therefore, we provide only additional observations within the framework of those given by Urquhart.

\section{Results}

Phylogenetic relationships

We obtained 915- and 1041-bp fragments of the $c y t b$ and $n d 2$ genes, respectively. Different tree-building methods (ML, MP, and NJ) all produced trees with a congruent topology (Fig. 2), therefore, only the ML tree obtained from the combined data set is shown in this communication. Saxicola rubicola, $S$. dacotiae and $S$. maurus form a clade (94\% bootstrap support) representing stonechats from Europe and Asia. The African stonechats S. torquatus axillaris, $S$. tectes and $S$. torquatus sibilla form a separate clade (92\% bootstrap support). Saxicola tectes and $S$. $t$. sibilla are both monophyletic (100\% bootstrap support) and cluster as sibling species. Saxicola t. sibilla forms a distinct clade in all tree reconstructions, indicating a separate evolutionary lineage, while $S$. caprata and $S$. rubetra take basal positions (100 and $95 \%$ bootstrap support) in the stonechat tree.

\section{Genetic distances}

Genetic distances ( $P$-distances) were obtained from the combined data set $(c y t b+n d 2$; see Table 2$)$. The genetic distance between the African $S$. $t$. axillaris and $S$. tectes from La Réunion was 5.3\%. The Malagasy S. t. sibilla is separated from $S$. t. axillaris by $4.9 \%$ and from $S$. tectes by 4.3\%. Within the Eurasian stonechat taxa (Siberian and European) inter-specific distances are in the same range $(4.5-4.9 \%)$. The variation within each taxon studied was low ( $P$-distances $<1 \%$ ), and most of the birds from the same region presented identical sequences (except for S. t. axillaris from Kenya and Tanzania, which differed by $2.1 \%$ and are therefore less related than expected). Since the genetic distances between $S$. $t$. sibilla and other stonechats from mainland Africa and from La Réunion range from 4 to $5 \%$ and taking into account that these distances were far larger than those within individual species, S. $t$. sibilla can be considered to form a separate and distinct genetic lineage. If we assume the $2 \%$ rule for a molecular clock of protein-coding mitochondrial genes (Wilson et al. 1987; Tarr and Fleischer 1993), then S. t. sibilla, S. tectes 
Fig. 2 Maximum likelihood (ML) tree based on a combined data set of the mitochondrial cytochrome $b$ gene (cytb) and the NADH dehydrogenase subunit $2(n d 2)$ gene. ML bootstrap values $\geq 50 \%$ (1000 replicates) are indicated for each node. The ML model selected was GTR $+\mathrm{I}=0.443+\Gamma=$ 0.989. ML tree $-\ln L=8665.02$

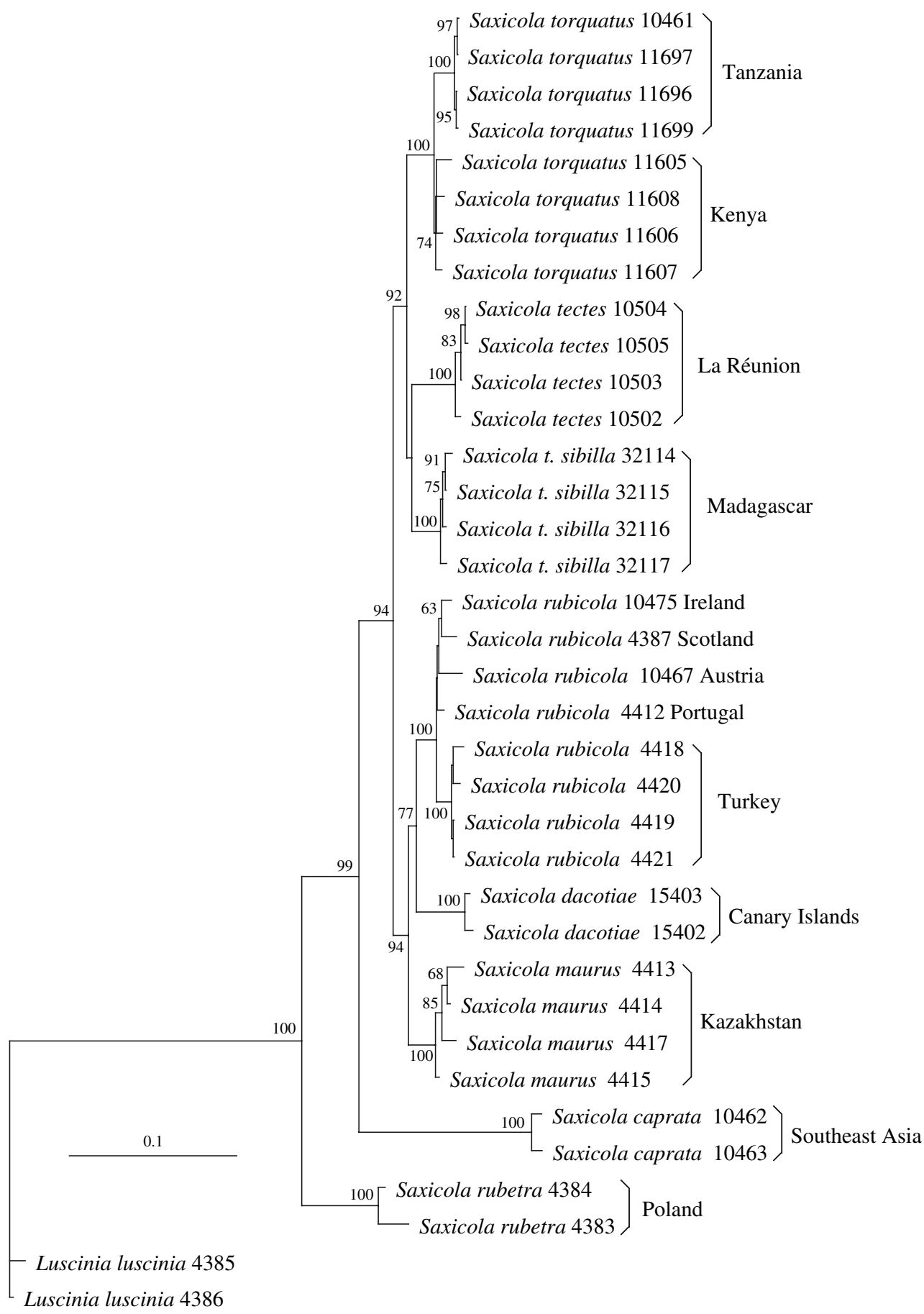

The outermost primary (P10) is 19-22 mm long and, when the wing is folded, the tip of $\mathrm{P} 9$ falls opposite to $\mathrm{P} 3$ and $\mathrm{P} 4$ or falls between them (on rare occasions it may fall between $\mathrm{P} 2$ and P3). The wing tip $(n=38)$ is formed by P7 (68\%), by P6 and P7 (13\%), by P6 (16\%) and very rarely by $\mathrm{P} 8(3 \%)$. The primary projection is similar to that of $S$. rubicola, relatively short and rounded, with the wing point extending over about half the length of the overlying tertials (see Urquhart 2002, p 182). 
Table 2 Matrix of $P$-distances (mean values) for $c y t b$ and $n d 2$ genes

\begin{tabular}{|c|c|c|c|c|c|c|c|c|}
\hline Taxon & 1 & 2 & 3 & 4 & 5 & 6 & 7 & 8 \\
\hline 1. S. rubetra & - & 9.9 & 9.9 & 10.6 & 12.3 & 10.5 & 9.8 & 11.1 \\
\hline 2. S. rubicola & & - & 4.5 & 4.7 & 11.6 & 6.0 & 5.4 & 6.1 \\
\hline 3. S. maurus & & & - & 4.9 & 11.3 & 5.3 & 5.4 & 5.9 \\
\hline 4. S. dacotiae & & & & - & 11.4 & 6.3 & 5.7 & 6.6 \\
\hline 5. S. caprata & & & & & - & 10.9 & 11.0 & 11.2 \\
\hline 6. S. tectes & & & & & & - & 4.3 & 5.3 \\
\hline 7. S. t. sibilla & & & & & & & - & 4.9 \\
\hline 8. S. t. axillaris & & & & & & & & - \\
\hline
\end{tabular}

Male stonechats S. t. sibilla have a black bill; their legs, upper parts, entire head, chin and throat are also black, and the chest, upper breast and occasionally the flanks are chestnut. The extent of black on the throat and chestnut on the breast has been used to describe subspecies by some authors. However, in some cases, the extent of chestnut seems to vary more between individuals than between taxa. For example, in contrast to the illustrations in Urquhart (2002), the chestnut of S. t. sibilla captured in the field and of those photographed in the collections was very rarely restricted to a small crescent; even in very worn plumage it varied from small to large, extending well onto the flanks. This variation was only partly explained by feather wear, and there was no geographic pattern (Fig. 3). This large individual variation is also known from other Saxicola taxa, such as captive S. t. axillaris from Kenya (B Helm, personal observation).

The black tail feathers have-very rarely-some white at their bases; their cream-coloured edges can be up to $3 \mathrm{~mm}$ wide in fresh S. t. sibilla (best seen from below). In worn plumage, these tips disappear entirely. The rump is pale, and individual feather tips are chestnut in fresh plumage, but appear white when abraded. The warm chestnut edges on the mantle, scapulars and tertials become an increasingly duller brown with age, possibly due to bleaching by the sun. In fresh plumage, the black throat feathers sometimes have white tips up to $1 \mathrm{~mm}$ long, but in some individuals these tips are missing even when the plumage is fresh. They have broad, white- to creamcoloured fringes on the remiges (best visible when checked from below; see also Urquhart 2002). In fresh plumage, the underwing coverts of male $S$. $t$. sibilla have black bases with white tips often appearing as a mix of white and black (white in $17 \%$, mixed in $71 \%$ and black in $12 \%$ of the birds, $n=42$ ). In worn plumage, the axillaries may appear as an almost pure black.

Female $S$. $t$. sibilla differ from males by their less contrasting plumage. Their heads are brown and their upper parts dark brown to lighter brown when bleached out. Their rump is chestnut to light brown and occasionally shows some white in the centre of individual rump feathers. Only in very worn plumage does the rump appear predominantly white. Because females were underrepresented in the collections and rarely caught, we are not able to provide more accurate information about them.

As in many passerines, male stonechats from Madagascar are larger than females. Differences in wing length, tarsus, most beak measurements and Kipp index were significant (Table 3). There was no difference in tail length or weight.

\section{Discussion}

Our results based on mtDNA indicate that the Saxicola populations we have investigated here are genetically distinct and that stonechats from Eastern Madagascar differ from their geographic neighbours $S$. t. axillaris and S. tectes by a considerable sequence divergence $(4.3-5.3 \%)$. As taxon sampling on Madagascar was limited to one site, we do not know how genetically divergent stonechats are

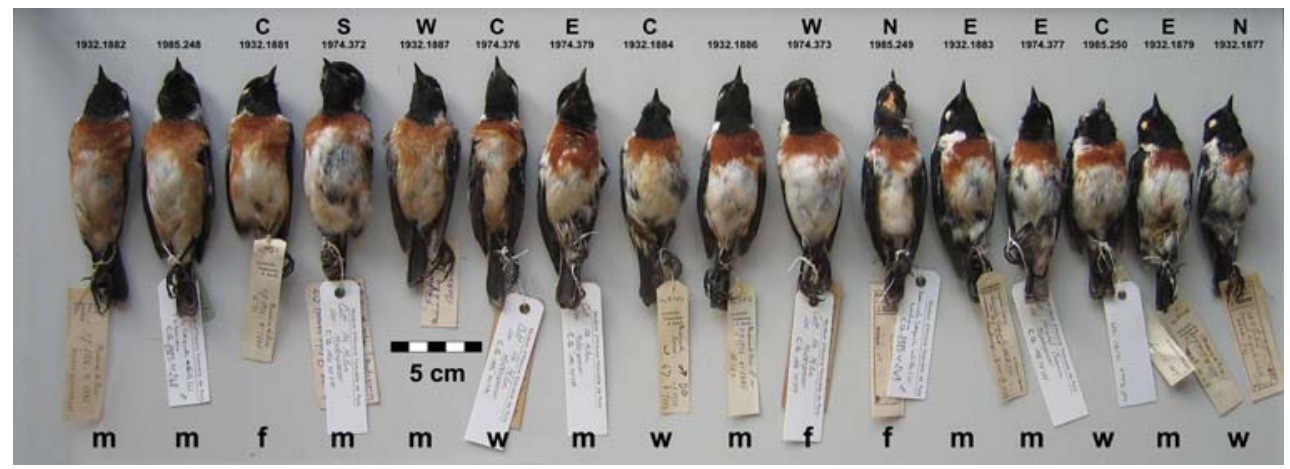

Fig. 3 Individual variation in the extent of the chestnut chest, upper belly and black throat in $S$. $t$. sibilla. $C$ Central Madagascar, $N$ north, $S$ south, $E$ east, $W$ west, $f$ fresh plumage, $w$ worn plumage, $m$ intermediate plumage. The numbers indicate collection numbers of the Muséum d'Histoire Naturelle Paris 
Table 3 Measurements (mm) of male and female stonechats from Madagascar taken from museum skins and weight ( $\mathrm{g}$ ) of live birds from Maromizaha

\begin{tabular}{|c|c|c|c|c|c|}
\hline \multirow[t]{2}{*}{ Variable $(\mathrm{mm})$} & \multicolumn{2}{|c|}{ Males } & \multicolumn{2}{|c|}{ Females } & \multirow{2}{*}{$\begin{array}{l}\text { Difference between } \\
\text { males and females } \\
t, P, d f\end{array}$} \\
\hline & $\bar{n}$ & Mean \pm SE (range) & $\bar{n}$ & Mean \pm SE (range) & \\
\hline Wing & 40 & $69.3 \pm 0.4(65.0-73.0)$ & 13 & $67.3 \pm 0.4(65.0-69.5)$ & $3,42,0.002 *, 32$ \\
\hline Tail & 39 & $50.8 \pm 0.4(46.0-54.0)$ & 13 & $49.9 \pm 0.5(47-53)$ & $1.52,0.14,30$ \\
\hline Tarsus & 37 & $24.4 \pm 0.2(22.5-27.0)$ & 11 & $23.8 \pm 0.2(23.0-25.0)$ & $2.2,0.04 *, 28$ \\
\hline Skull & 37 & $16.2 \pm 0.1(15.2-17.1)$ & 13 & $15.7 \pm 0.1(15-16.5)$ & $3.49,0.002 *, 26$ \\
\hline Bill length & 36 & $8.1 \pm 0.1(7.2-8.7)$ & 13 & $7.8 \pm 0.1(7.2-8.4)$ & $2.17,0.04 *, 20$ \\
\hline Bill width & 36 & $4.1 \pm 0.0(3.5-4.5)$ & 13 & $3.9 \pm 0.1(3.5-4.3)$ & $2.30,0.03^{*}, 21$ \\
\hline Bill depth & 36 & $3.8 \pm 0.1(3.4-4.5)$ & 13 & $3.8 \pm 0.1(3.4-4.1)$ & $0.25,0.81,25$ \\
\hline Kipp index & 29 & $17.4 \pm 0.2(14.7-19.6)$ & 12 & $16.4 \pm 0.4(14.0-18.4)$ & $2.21,0.04 *, 16$ \\
\hline Weight & 18 & $15.6 \pm 0.25(13.3-17.4)$ & 6 & $16.5 \pm 0.59(14-18.1)$ & $1.38,0.21,6$ \\
\hline
\end{tabular}

* Significant at $P<0.05$

$t$ Tests were carried out to test for differences between males and females

within Madagascar. Furthermore, the status of S. torquatus ankaratrae (Salomonsen 1934) and S. torquatus tsaratananae (Milon 1950) still needs to be clarified. Nevertheless, based on our results, it is very likely that Malagasy stonechats, Saxicola torquatus sibilla (Linnaeus 1766), can be assigned species rank: Saxicola sibilla (Linnaeus 1766).

Our molecular data do not allow a complete reconstruction of the phylogenetic relationships, radiation, and evolution of stonechats (Wink et al. 2002a, b) and because some crucial regions in Africa were not sampled, the African sister group of the Malagasy/Réunion clade could not be identified with certainty. Additional taxa of the Saxicola-complex from Madagascar, Africa and Asia need to be included in the analysis to further clarify the systematic position and the biogeographical background of this assemblage. A more complete phylogenetic picture could inspire evolutionary scenarios of stonechat radiation and guide the interpretation of geographically distinct behavioural characteristics that have been described in this taxonomic group (Gwinner et al. 1983; Dittami and Gwinner 1985; Helm et al. 2005; Helm and Gwinner 2006).

\section{Zusammenfassung}

Die taxonomische Stellung des

Madagaskarschwarzkehlchens (Saxicola torquatus

sibilla) anhand von Nukleotidsequenzen

mitochondrialer DNA

Schwarzkehlchen (Gattung Saxicola) sind Singvögel mit einer außergewöhnlich weitläufigen Brutverbreitung in der Alten Welt. Neuere Studien belegen, dass dieses Taxon eine weit stärkere geografische Differenzierung aufweist, als ursprünglich angenommen: So sind Afrikanische,
Sibirische und Europäische Schwarzkehlchen deutlich verschiedenen monophyletischen Gruppen zuzuordnen und werden von manchen Autoren als eigene Arten angesehen. In der vorliegenden Arbeit stellen wir neue Untersuchungen zur geografischen Differenzierung innerhalb des Afrikanischen Schwarzkehlchens, Saxicola torquatus, vor. Die Analyse von Nukleotidsequenzen mitochondrialer NADH Dehydrogenase Untereinheit 2 und Cytochrome $b$ Gene ergaben, dass Schwarzkehlchen aus dem Osten Madagaskars (Saxicola t. sibilla) eine eigene Gruppe darstellen. Gemeinsam mit Schwarzkehlchen des ostafrikanischen Festlandes (Saxicola $t$. axillaris) und dem Réunionschwarzkehlchen (Saxicola tectes) bilden sie eine monophyletische Gruppe.

Genetische und morphologische Daten legen nahe, dass das Madagaskarschwarzkehlchen sehr wahrscheinlich als eigene Art anzusehen ist: Saxicola sibilla (Linnaeus 1766). Eine genaue Beschreibung des Gefieders und verschiedener äußerer Körpermaße wird gegeben. Weitere vergleichende genetische, morphologische und bioakustische Untersuchungen von Taxa aus dem afrikanischen Saxicola-Komplex sind erforderlich, um die phylogenetische Stellung sowie die biogeografische Entwicklung der madagassischen Schwarzkehlchen abschließend zu klären.

Acknowledgments We are indebted to the Malagasy Government for the permission to carry out parts of this research. Furthermore, our appreciation goes to the "NAT"-foundation for inviting us to work at Maromizaha. We thank our Malagasy colleagues at the University of Antananarivo, at ANGAP, the Ministère de l'Environnement, des Eaux et Forêts, Frank Hawkins from Conservation International and all the people that helped us in the field. The "Gesellschaft zur Förderung des Naturkundemuseums Stuttgart" funded part of this research. Hedi Sauer-Gürth (IPMB. Heidelberg) kindly sequenced the cytochrome $b$ gene. We thank Heidrun and Jochen Albrecht, HansHeinrich Witt, Alexander Scheuerlein and Ingrid Schwabl for collecting samples. We also thank Eric Pasquet (Muséum National 
d'Histoire Naturelle, Paris), Sylke Frahnert (Museum für Naturkunde, Berlin) and Renate v.d. Elzen (Museum Alexander Koenig, Bonn) for kindly granting access to their bird collections. We thank Prof. Dr. H. Bock (Managing Director of IWR) and S. Friedel for access to parallel computing facilities at the Interdisciplinary Centre for Scientific Computing (IWR, Heidelberg University). T.C.H. Cole made valuable comments that improved this manuscript. We also thank two anonymous reviewers. All observations, field work and sampling complied with the regulations of the countries in which the study was carried out.

\section{References}

Britton PL (ed) (1980) Birds of East Africa. East Africa Natural History Society, Nairobi

Dittami JP, Gwinner E (1985) Annual cycles in the African stonechat Saxicola torquatus axillaris and their relationship to environmental factors. J Zool Lond A 207:357-370

Gwinner E, Dittami J, Gwinner H (1983) Postjuvenile molt in East African and Central European stonechats (Saxicola torquata axillaris, $S$. t. rubicula) and its modification by photoperiod. Oecologia 60:66-70

Hall TA (1999) BıoEdIT: a user-friendly biological sequence alignment editor and analysis program for Windows 95/98/NT. Nucleic Acids Symp Ser 41:95-98

Helm B, Gwinner E (2006) Migratory restlessness in an equatorial non-migratory bird. PloS Biol 4:611-614

Helm B, Gwinner E, Trost L (2005) Flexible seasonal timing and migratory behavior: results from stonechat breeding programs. In: Bird hormones and bird migrations. Analyzing hormones in droppings and egg yolks and assessing adaptations in longdistance migration. Ann N Y Acad Sci 1046:216-227

Keith S, Urban EK, Fry CH (1992) The birds of Africa. Broadbills to chats, vol 4. Academic Press, London

Kimura M (1980) A simple method for estimating evolutionary rate of base substitutions through comparative studies of nucleotide sequences. J Mol Evol 16:111-120

Kipp FA (1959) Der Handflügelindex als flugbiologisches Maß. Vogelwarte 20:77-86

Langrand O (1990) Guide to the birds of Madagascar. Yale University Press, New Haven, London

Milon P (1950) Les formes de Saxicola torquatus à Madagascar. Bull Mus Hist Nat Paris 2:705-708
Minitab (2005) Meet Minitab. Release 14 for Windows. Minitab, State College, PA

Morris P, Hawkins F (1998) In: Redman N (ed) Birds of Madagascar. A photographic guide. Pica Press, East Sussex

Posada D, Crandall KA (1998) Model test: testing the model of DNA substitution. Bioinformatics 14:817-818

Redfern PF, Clark JA (2001) Ringers' manual. BTO, Thetford

Salomonsen F (1934) On a hitherto unknown fauna of montane birds in Central Madagascar. Novitates Zool 39:207-215

Scheuerlein A, Gwinner E (2006) Reduced nestling growth of East African stonechats Saxicola torquata axillaris in the presence of a predator. Ibis 148:468-476

Swofford DL (2001) PAUP. Phylogenetic analysis using parsimony. Version 4.06. Sinauer, Sunderland

Tamura K, Dudley J, Nei M, Kumar S (2007) MEGA 4: Molecular evolutionary genetics analysis (MEGA) software version 4.0. Mol Biol Evol 24:1596-1599

Tarr CL, Fleischer RC (1993) Mitochondrial DNA variation and evolutionary relationships in the Amakihi complex. Auk 110:825-831

Urquhart E (2002) Stonechats. A.C. Black, London

Wilson AC, Ochman H, Prager EM (1987) Molecular time scale for evolution. Trends Genet 3:241-247

Wink M (2000) Advances in DNA studies of diurnal and nocturnal raptors. In: Chancellor RD, Meyburg B-U (eds) Raptors at risk. WWGBP/Hancock House, Berlin/Blaine, pp 831-844

Wink M (2006) Use of DNA markers to study bird migration. J Ornithol 147:234-244

Wink M, Sauer-Gürth H, Gwinner E (2002a) A molecular phylogeny of stonechats and related turdids inferred from mitochondrial DNA sequences and genomic fingerprinting by ISSR-PCR. Br Birds 95:349-355

Wink M, Sauer-Gürth H, Heidrich P, Witt H-H, Gwinner E (2002b) A molecular phylogeny of stonechats and related turdids. In: Urquhart E (ed) Stonechats. A.C. Black, London, pp 23-30

Wittmann U, Heidrich P, Wink M, Gwinner E (1995) Speciation in the stonechat (Saxicola torquatus) inferred from nucleotide sequences of the cytochrome $b$ gene. J Zoo Syst Evol Res 33:116-122

Zink RM, Pavlova A, Rohwer S, Drovetski SV (2006) Barns swallows before barns: population histories and intercontinental colonization. Proc R Soc B 273:1245-1251 